Peer-Reviewed Article

ISSN: 2162-3104 Print/ ISSN: 2166-3750 Online

Volume 6, Issue 4 (2016), pp. 933-955

(C) Journal of International Students

http://jistudents.org/

\title{
International Undergraduates' Retention, Graduation, and Time to Degree
}

\author{
Barry Fass-Holmes \\ University of California, San Diego, USA
}

\begin{abstract}
The present study tested the hypothesis that the international undergraduates at a West Coast American public university during recent years of dramatic enrollment growth should have low retention and graduation rates. This study showed instead that these students were retained and graduated at rates surpassing predictions from research and theories on international undergraduates' unique challenges (American immigration regulations, academic integrity standards, and teaching methods; English writing) and academic struggles. Moreover, contrary to predictions related to academic struggles, the primary reasons for these students' attrition were leave of absence for compulsory military service and deciding against attending the University. These results disconfirm the study's hypothesis and instead suggest that these international undergraduates generally have succeeded academically.
\end{abstract}

Keywords: attrition, graduation, international students, retention, satisfaction, student success

Retention and graduation rates are important indicators of student success (Kuh, Kinzie, Buckley, Bridges, \& Hayek, 2006). These indicators have been defined as "the percentage of a school's first-time, first-year undergraduate students who continue at that school the next year" and "the percentage of a school's first-time, first-year undergraduate students who complete their program within $150 \%$ of the published time for the program," respectively (U.S. Department of Education, n.d.). In addition to their importance for student success, retention and graduation rates are used for accountability purposes (Gold \& Albert, 2006), enrollment-related funding and management (Berger, Ramírez, \& Lyons, 2012), and compliance with the federal Student Right to Know and Campus Security Act (Cook \& 
Pullaro, 2010). They also have attracted the attention of elected officials who have called for American universities to improve their students' retention and graduation rates (Asimov \& Gutierrez, 2015; Obama, 2009).

Efforts to improve retention and graduation rates at American postsecondary institutions recently have become more complicated due to the dramatic increase in their nonimmigrant international student populations. These institutions have admitted and enrolled increasing numbers of students from other countries in the years after the great recession of 2008. According to the Institute of International Education's (IIE) annual Open Doors reports, this increase amounted to $2.9 \%$ in 2009 $10,4.7 \%$ in $2010-11,5.7 \%$ in $2011-12,7.2 \%$ in $2012-13,8.1 \%$ in $2013-14$, and $8.8 \%$ in 2014-15 (IIE, 2015a). First-time international undergraduates' enrollment in American universities increased by $1.3 \%$ in $2009-10,5.7 \%$ in $2010-11,6.5 \%$ in $2011-12,9.8 \%$ in $2012-13$, $7.7 \%$ in $2013-14$, and $3.0 \%$ in 2014-15 (IIE, 2015a).

Increased international student enrollment has led administrators, faculty, and staff at a West Coast public university (hereafter referred to as "the University") which has been recognized for its excellence in academics and research (U.S. News and World Report, 2015) to become increasingly concerned about these students' prospects for academic success (see also Oliver, Vanderford, \& Grote, 2012). Specifically, the concern is that international undergraduates collectively struggle academically (term grade point average [GPA] below 2.0 [C]) due to English weakness (Fass-Holmes \& Vaughn, 2014). Concern at the University has increased despite historically strong support for international students through a wide variety of programs and services intended to optimize these students' satisfaction and engagement (Fass-Holmes \& Vaughn, 2014), and thereby promote their retention and graduation (Tinto, 1975). To the extent that this concern is justified, however, the University's retention and/or graduation rates could be compromised by its international undergraduates' academic struggles.

In addressing the above concern, the primary purpose of the present study was to measure retention and graduation rates of the University's international undergraduates, and to determine these rates' values during the six most recent academic years (AY) when nonresident enrollment grew dramatically (Dorado \& Fass-Holmes, 2016). This study's results were expected to reveal whether these rates supported the concern that the University's international undergraduates collectively were struggling academically. The research hypothesis was that if these students in fact were collectively struggling, then their retention and graduation rates should be commensurately low.

Two secondary purposes of this study were to measure the time to degree for the University's international undergraduates who did graduate during the five most recent AYs, and to identify what reasons were 
responsible for the University's international undergraduates not to be retained or graduate. The time to degree measurement could further reveal the extent to which the concern about these students' academic struggles was empirically supported. The analysis of reasons why these students were not retained and/or did not graduate also was expected to address this concern; if international undergraduates in fact were collectively struggling academically, then the ones who were not retained and/or did not graduate should have done so as a consequence of low GPAs.

\section{LITERATURE REVIEW}

The following literature review addresses the following three research themes: international undergraduates' challenges while attending American universities; retention and graduation; and international undergraduates' academic struggles at the University. These themes provide the necessary context for the present research study's goals as explained below.

\section{International students' challenges}

International undergraduates (especially ones whose native language is not English) have been reported to experience various challenges which impact their success at American universities (Gautam, Lowery, Mays, \& Durant, 2016; Perry, 2016). These challenges include (but are not limited to) acculturative stress (Jackson, Ray, \& Bybell, 2013; Yan \& Berliner, 2013), American academic integrity standards (Bista, 2011), American teaching methods (Ota, 2013; Roy, 2013), campus climate (Ota, 2013), discrimination (Ota, 2013), English language (Andrade, 2006a; Ota, 2013; Sherry, Thomas, \& Chui, 2010; Yan \& Berliner, 2013), family expectations (Ota, 2013), finances (Mamiseishvili, 2012; Sherry et al., 2010; Yan \& Berliner, 2013), homesickness and/or loneliness (Andrade, 2006a; Ota, 2013; Sherry et al., 2010), interpersonal interactions (Roy, 2013), social norms (Ota, 2013; Sherry et al., 2010), and study practices (Yildirim, 2014). Although many of these challenges also could be experienced by domestic undergraduates, some of them uniquely affect international undergraduates.

One challenge uniquely affecting international students is English writing. All international (and some domestic) students for whom English is a second language might experience challenges with English grammar (e.g., articles, verb tenses, word order), pronunciation (e.g., consonant clusters, intonation, phonology, syllables, vowels), and/or vocabulary (e.g., phrasal verbs) (Frankfurt International School, n.d., a, b; Yin-Croft, 2012). However, students from Asian and Middle Eastern countries (who constitute a majority of all international students attending American universities; IIE, 2015b) are likely to experience unique challenges with English writing. These students' countries have a number of localized dialects (Arab 
Academy, 2010; Japanese-Language, n.d.; Languages of China, n.d.) that uniquely differ from English with regard to their written form. For example, China's Mandarin language has a logographic system of writing (rather than an alphabet) in which characters represent whole words (Frankfurt International School, n.d., a). Arabic also differs from English in its written form, specifically its directionality (right to left) and style (cursive script without upper and lower case) (Frankfurt International School, n.d., b). These fundamental differences between Asian and Middle Eastern languages versus English could be more problematic for international students than American universities recognize (Benzie, 2010; Center for Research on Learning and Teaching, 2016; Leong, 2015; Lin \& Scherz, 2014; Ren, Bryan, Min, \& Wei, 2007). Asian and/or Middle Eastern students might struggle with writing even though their scores on standardized tests of English proficiency meet universities' admissions requirements (Fass-Holmes \& Vaughn, 2014; Oliver et al., 2012; Vaughn, Bergman, \& Fass-Holmes, 2015). Consequently, these students' unique challenges with English could be related to writing difficulties which, in turn, could impair performance on exams and term papers (Kuo, 2011; Unruh, 2015). Thus, the above difficulties could uniquely jeopardize international students' graduation and/or retention.

Another challenge which international undergraduates experience at American universities, but domestic counterparts do not, is mandatory compliance with federal immigration regulations (Urias \& Leakey, 2009). These students must comply with regulations for reporting to the federal government's Student and Exchange Visitor Information System database (NAFSA: Association of International Educators, 2016) which include (but are not limited to): maintaining full-time enrollment (a minimum of 12 hours) each semester or quarter; attending and passing all courses; and obtaining an extension of the official program of study's end date if additional time is required to complete degree requirements. Noncompliance with the regulations could result in termination of the student's Form I-20 (U.S. Immigration and Customs Enforcement, 2015), which consequently could result in detainment at U.S. ports of entry when the student travels (Feal, 2008). Detainment can be a frightening and/or stressful experience for international students (Mantle, 2003; Urias \& Yeakey, 2005) in addition to ending and/or interrupting their educational program of study in America. International students who fail to comply with U.S. regulations therefore could experience adverse effects on their graduation and/or retention which domestic students do not.

A third challenge which international students could uniquely experience at American universities is lack of familiarity with Western academic integrity standards and/or teaching methods (Hanassab \& Tidwell, 2002; Sherry et al., 2010; Simpson, 2016). Although academic integrity 
standards at American universities apply to all enrolled students, internationals could be more vulnerable to violations of integrity standards than domestic counterparts (Bertram Gallant, Binkin, \& Donohue, 2015). Their vulnerability, as documented in the educational research literature, has been attributed (at least in part) to a lack of familiarity with American standards for academic integrity (e.g., Lupton et al., 2000; Mori, 2000). For instance, international students reportedly are unfamiliar with plagiarism standards because of their home countries' culture, learning methods, and teaching styles (Bista, 2011). Plagiarism standards additionally are unfamiliar to students from countries where using another person's work as if it were one's own is viewed as flattery or is an unintended side effect of collectivism, memorization, and group work rather than as an integrity violation (Simpson, 2016). Because American universities typically expel students found guilty of academic integrity violations, international students' vulnerability to cheat could have serious consequences for retention and graduation (Fass-Holmes, in press).

Besides their lack of familiarity with American academic integrity standards, a fourth challenge is that international students (especially ones enrolling at a U.S. school for the first time) could be uniquely unfamiliar with American teaching methods (Smithee, Greenblatt, \& Eland, 2004; Unruh, 2015). For example, international students reportedly are unfamiliar with America's learner-centered classroom culture (Smithee et al., 2004). International students' lack of familiarity with American teaching methods additionally is acknowledged in the federal regulations which require international students to maintain full-time enrollment every semester. These regulations specify that a reduced course load may be approved for three reasons related to academic difficulties, one of which is "unfamiliarity with U.S. teaching methods" (NAFSA: Association of International Educators, 2016).

\section{Retention and graduation}

The above four challenges which international students uniquely experience, in addition to the ones they experience in common with domestic counterparts, would lead to the prediction that international students' retention and graduation should be adversely affected. English writing difficulties, academic integrity violations due to unfamiliarity with American standards, and lack of familiarity with American teaching methods should contribute to international students' academic struggles. To the extent that their struggles consequently result in poor grades and low GPAs, these students should be at risk of academic probation or disqualification (the latter would lead to dismissal). The extent to which international students consequently are dismissed for poor academic performance should lead their retention and graduation rates (respectively) 
to be commensurately low because retention and graduation would be prevented by dismissal.

How can international students' retention and graduation rates be explained or predicted, taking into account these unique challenges? Numerous student retention models and theories have been published (Aljohani, 2016), including Tinto’s Institutional Departure Model (1975), Bean's Student Attrition Model (1980, 1982), the Student-Faculty Informal Contact Model (Pascarella, 1980), Astin's Student Involvement Model (1984), the Non-traditional Student Attrition Model (Bean \& Metzner, 1985), and the Student Retention Integrated Model (Cabrera, Nora, \& Castaneda, 1993). These models and theories address factors and variables (e.g., affordability, lack of access to jobs, and transfer to another university) which have been shown to influence students' decision to leave school prior to completion (Choudaha \& Schulmann, 2014). However, they do not account for international students' unique challenges because 1) the above models and theories were developed and published well before the dramatic increase following the great recession of 2008, when the numbers of international students attending American postsecondary institutions represented a fraction of total enrollment (IIE, 2015a); and 2) unlike the factors and variables which lead students to decide to leave school and which are addressed in student retention models and theories (Aljohani, 2016), these unique challenges are factors which influence universities' decision that international students will leave school (be dismissed) prior to completion. For these two reasons, the unique challenges which affect international students are not specifically addressed in student retention models and theories (Di Maria \& Kwai, 2014). These models and theories consequently would be limited in explaining and/or predicting international students' retention and graduation.

Although student retention models and theories do not specifically account for international students' unique challenges, numerous studies based upon these models and theories have been conducted to identify reasons why internationals decide to leave school (e.g., Andrade, 2006b; Choudaha \& Schulmann, 2014; Kwai, 2009; Schulmann \& Choudaha, 2014). Many of these studies reported useful qualitative information based upon interviews and/or focus groups. However, relatively few studies have been published which report quantitative data on international undergraduates' retention or graduation rates. One example is Meagher's (2014) internet-based interactive chart which shows 2013's top 200 nationally ranked universities' 6-years graduation rates for international undergraduates (ranging from Stanford University's 100\% to University of North Carolina at Chapel Hill's 42\%) with an average of $70 \%$. Additional quantitative data like these for multiple entering classes, disaggregated by applicant type (first-time freshmen versus transfers), likely would be 
informative and useful to administrators, instructors, and international education researchers.

\section{International undergraduates' academic struggles at the University}

The University's increase in international student enrollment following the great recession of 2008 has led to heightened concern among administrators, faculty, and staff that their international students collectively struggle academically. This concern has intensified despite historically strong support. A diversity of mandatory and voluntary programs and services (Fass-Holmes \& Vaughn, 2014) is offered to optimize international students' academic and social integration, thereby promoting their retention and graduation (Tinto, 1975). For example, all of the University's newly admitted international students are required to attend an orientation that includes segments on academic integrity and American teaching methods.

The concern that the University's international undergraduates collectively struggle academically, however, has not been supported by research findings. A recent study showed instead that the mean term GPA earned by these students was 3.24-3.33 (roughly between $\mathrm{B}$ and $\mathrm{B}+$ ), and that at most $10 \%$ of them struggled (term GPA below C) (Fass-Holmes \& Vaughn, 2014). Moreover, the University's international undergraduates evidently have succeeded academically despite difficulties with English; more than $60 \%$ of these students failed the University's English writing proficiency requirement, then earned average academic marks between $\mathrm{D}+$ and C- in mandatory English composition and/or English as a second language classes, yet their term GPAs (which excluded these classes) were between B and B+ (Fass-Holmes \& Vaughn, 2014). These findings were met with a skepticism which responded that degree-seeking international transfer undergraduates (TRAN) who previously attended community colleges must be the academically struggling students. This skepticism also was not supported by research findings - another study showed that 1) five cohorts of TRAN earned first-year mean GPAs between B- and B, 2) less than $12 \%$ earned GPAs below $C$, and 3 ) less than $15 \%$ were in bad academic standing (probation, subject to disqualification, or dismissed) (Dorado \& Fass-Holmes, 2016).

In summary, research studies on the University's international undergraduates have not confirmed concerns that these students collectively struggle academically, that TRAN who previously attended community colleges are the ones who struggle academically or that these students choose their major field based upon its dependence upon English writing proficiency. Instead, these studies have shown that the University's international undergraduates in general have succeeded academically. One key missing data point with regard to these students' success, however, 
would be their retention and graduation rates. These metrics of student success therefore were measured in the present study.

\section{Objectives}

The present research study's primary objective was to test the hypothesis that international undergraduates attending the University during the time corresponding to the recent period of dramatic enrollment growth (Dorado \& Fass-Holmes, 2016) should have low retention and graduation rates. A second objective was to measure the time to degree for the University's international undergraduates who did graduate; if these students struggled academically, they should have required additional years to complete their degree requirements. This study's third objective was to identify what reasons were responsible for the University's international undergraduates to not be retained. If these students in fact were collectively struggling academically, then the ones who were not retained should have had low GPAs.

The following questions were addressed in the present study. How many and what percentage of international first-time freshmen (NFRS) and TRAN were retained in their second fall term at the University? How many and what percentage of international NFRS and TRAN graduated from the University? What reasons were responsible for NFRS and TRAN who did not graduate and/or were not retained? What percentage was due to low GPAs (academic struggling)? For all international NFRS and TRAN who graduated from the University, regardless of the cohort to which they belonged, what was their time to degree?

\section{RESEARCH METHOD}

\section{Participants, data collection, and analyses}

Demographic data for international (F-1 or J-1 visa; U.S. Department of State, n.d.) NFRS and TRAN who submitted a statement of intent to register (SIR) at the University during at least one of the fall terms of AYs 2009-10 through 2014-15, inclusive, were extracted from the University's student information system database using structured query language programs (Vaughn et al., 2015). These six AYs' data were used in the present study because they were the most recent ones for which retention data were available, and because they coincided with the University's dramatic increase in international undergraduate enrollment (Dorado \& Fass-Holmes, 2016). The resulting records contained each student's unique campus ID plus values for demographic variables of interest-academic status, admit term/year, applicant decision (SIR), applicant type (NFRS or TRAN), class (freshman, etc.), citizenship country, degree conferred, department, education level (undergraduate), gender, major, registration 
status, term, and visa type; these records were organized in a spreadsheet file. To determine the reason why any given student was not retained, advisors' notes in the student records within the University's international students office's internal database were inspected and the relevant information was entered into the above spreadsheet. Confidentiality was ensured by following IRB approved procedures which involved encryption and statistical analysis of the spreadsheet's contents on a secured computer. Descriptive statistical analyses in spreadsheet software consisted of computing counts and percentages disaggregated by the above demographic variables as appropriate.

To compute counts and percentages for retention rates, each cohort's records were extracted from the University's student information system database for the initial fall term when the cohort's members submitted SIRs after receiving an admission offer. The cohort members' IDs then were used to match against extractions for the following AY's fall term; the match had as an additional condition that records for the following fall term had to have a registration status code indicating enrollment in and payment for classes. Therefore, cohort members who were retained in the following AY's fall term had a record in that extraction, cohort members who were not retained did not. Quality controls ensured that cohort members with double majors or multiple records were not double-counted. Computations then were based upon the number of records in the initial extraction (SIRs) versus the corresponding number which had matching IDs between the initial and following fall terms' extractions. Cohort members with conferred degrees were excluded from retention rate computations because they no longer were eligible to be retained.

This method was based upon an operational definition of "retention" (using number of SIRs) which underestimated retention rates and differed from the conventional one (the percentage of a school's first-time, first-year undergraduate students who continue at that school the next year; U.S. Department of Education, n.d.). It was used, however, to account for admitted international undergraduates who decided against attending the University in the initial fall terms (along with counterparts who left the University in the following fall terms because of finances, better fit at another institution, location, etc.; Choudaha \& Schulmann, 2014; Schulmann \& Choudaha, 2014). These students were quantified in this study's attrition analysis of reasons why students were not retained.

To compute counts and percentages for graduation rates, the cohort members' IDs in the above initial fall term records were used for matching against IDs in extractions from the University's student information system's database of conferred degrees. This was done for AYs up to and including 2014-15 (the most recent AY for which conferred degrees data were available at the time of this study). The resulting records contained 
each student's unique campus ID plus values for the demographic variables of interest (see above). Quality controls ensured that cohort members with double majors or multiple records were not double-counted. Computations then were based upon the number of records in the initial extraction versus the corresponding number which had matching IDs between the initial fall term's extractions and the extraction from the degrees conferred database. Because the conventional amount of time for NFRS to complete degree requirements was 4 years and for TRAN was 2 years, the FA13 and FA14 cohorts' graduation rates were expected to be low due primarily to insufficient time.

Time to degree was computed by extracting all international undergraduates' records from the University's student information system's database of conferred degrees, regardless of the cohort to which they belonged. The resulting records contained each student's unique campus ID plus values for demographic variables of interest which included admit term/year, applicant type (NFRS or TRAN), degree type, degree conferred term/year, education level (undergraduate), graduation date, and visa type. Students with double majors were counted twice-once for each degree conferred. Computations of time to degree (total number of years) were based upon the admit term/year value and degree conferred term/year value. Numbers of international undergraduates, mean times to degree, and standard deviations were computed for ones who graduated in AY 2010-11 (regardless of their admit term/year), in AY 2011-12 (regardless of their admit term/year), and so on through AY 2014-15 (the most recent year for which degrees conferred data were available at the time of this study). These computed values then were disaggregated by applicant type (NFRS vs. TRAN).

\section{RESULTS}

The total number of international undergraduates in each of the present study's six cohorts, disaggregated by applicant type (NFRS vs. TRAN), is shown in Figure 1. The fall 2009 (FA09) cohort had the smallest numbers of NFRS and TRAN; the fall 2014 (FA14) cohort had the largest. FA09, fall 2010 (FA10), and fall 2011 (FA11) cohorts had smaller numbers of NFRS than TRAN. However, this pattern reversed beginning with the fall 2012 (FA12) cohort-it had a larger number of NFRS than TRAN-and continued in the fall 2013 (FA13) and FA14 cohorts. The FA13 and FA14 NFRS cohorts both were more than 15 times larger than their FA09 counterpart. By contrast, the FA13 and FA14 TRAN cohorts both were less than 3 times as large as their FA09 counterpart. 


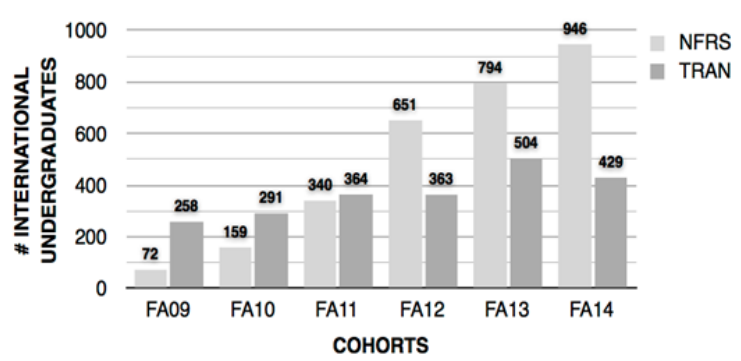

Figure 1. International (F-1 and $\mathrm{J}-1$ ) undergraduates in each of the study's six cohorts, disaggregated by applicant type. Values above the bars represent the number of incoming first-time freshmen (NFRS) or incoming transfer counterparts (TRAN).

Abbreviations: FA09=fall 2009; FA10=fall 2010; FA11=fall 2011, FA12=fall 2012; FA13=fall 2013; FA14=fall 2014

\section{Retention}

Retention rates for each of this study's six cohorts, disaggregated by applicant type (NFRS vs. TRAN), are shown in Figure 2. These rates ranged from just under $85 \%$ to $94 \%$ for NFRS, and from $84 \%$ to $90 \%$ for TRAN. Thus, at least $84 \%$ of the NFRS or TRAN who submitted SIRs were registered for classes in the fall term of the AY following their admit term/year at the University. The FA09 cohort had the highest NFRS retention rate; the FA14 cohort had the highest TRAN retention rate. Each cohort's NFRS retention rate was slightly higher than TRAN.

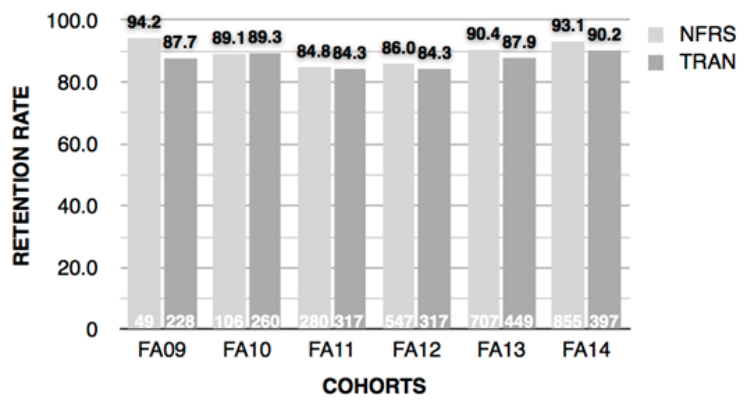

Figure 2. Retention rates of international undergraduates at the University, disaggregated by applicant type. Values above the bars are percentages; ones at the bottom are counts. For each of the study's six cohorts of first-time freshmen (NFRS) and transfers (TRAN), this figure shows the percentage who registered for classes in the fall term of the academic year after their admit year.

Abbreviations: FA09=fall 2009; FA10=fall 2010; FA11=fall 2011, FA12=fall 2012; FA13=fall 2013; FA14=fall 2014

\section{Graduation}

Graduation rates for each of this study's six cohorts, disaggregated by applicant type (NFRS vs. TRAN), are shown in Figure 3. These values ranged from $0 \%$ (1- and 2-year rates) to just under 83\% (6-year rate) for NFRS, and from just under 1\% (1-year rate) to just under 92\% (5-year rate) for TRAN. Thus, up to about $83 \%$ of the NFRS and $92 \%$ of the TRAN in this study's cohorts had graduated by the end of AY 2014-15. The FA09 cohort had the highest NFRS graduation rate (6 years); the FA10 cohort had 
the highest TRAN graduation rate (5 years). NFRS graduation rates were lower than TRAN for each cohort.

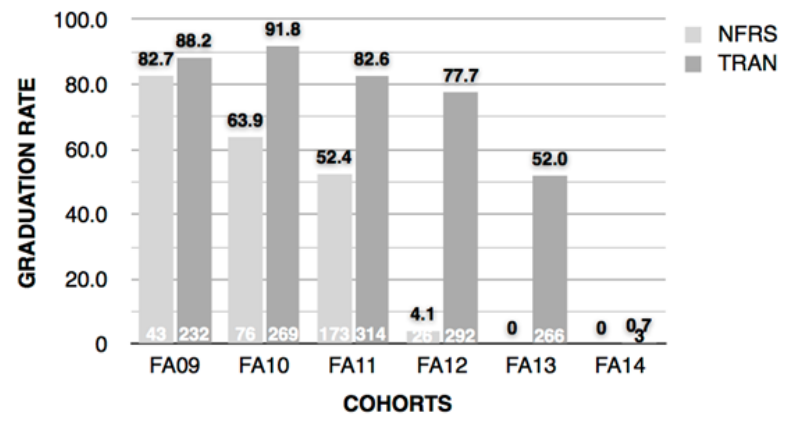

Figure 3. Graduation rates of international undergraduates at the University, disaggregated by applicant type. Values above the bars are percentages; ones at the bottom are counts. For each of the study's six cohorts of first-time freshmen (NFRS) and transfers (TRAN), this figure shows the percentage who graduated by the end of academic year 2014-15.

Abbreviations: FA09=fall 2009; FA10=fall 2010; FA11=fall 2011, FA12=fall 2012; FA13=fall 2013; FA14=fall 2014

\section{Attrition}

The graph in Figure 4 shows NFRS attrition data disaggregated by cohort. The number of NFRS who were not retained in the fall term following their admit term/year ranged from 3 (FA09 cohort) to 89 (FA12 cohort). The lowest percentage of these NFRS was 5.8 (FA09 cohort) and the highest was 15.2 (FA11 cohort). Thus, a maximum of about $15 \%$ of the NFRS in this study's cohorts was not retained. The two most frequent attrition reasons were leave of absence to serve in the military (South Korean males) and decided not to attend the University (i.e., NFRS who submitted SIRs but never attended classes at the University). Poor academic performance (resulting in disqualification or subject to disqualification) was the third most frequent reason. Other reasons were transferred to another institution, stopped attending the University, and academic dishonesty. For each of these reasons, within each cohort, the percentage was $5 \%$ or less (data displays available from the author upon request).

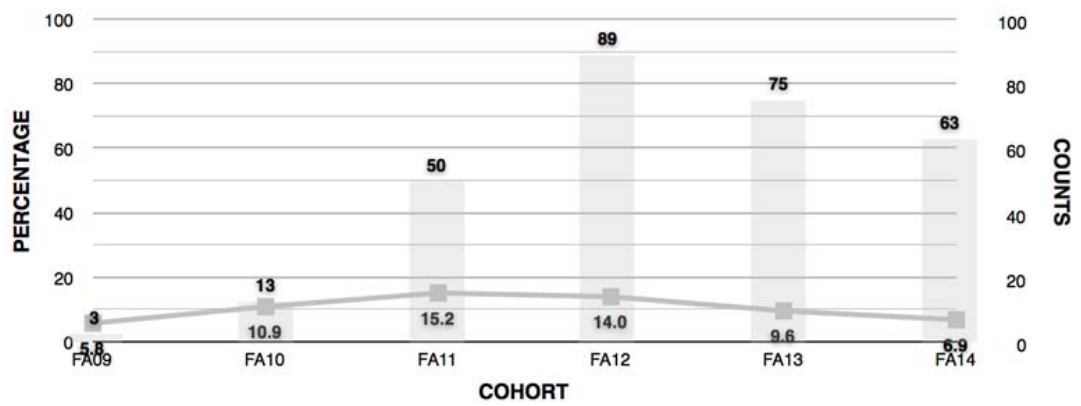

Figure 4. International first-time freshmen's (NFRS) attrition rates and reasons for not being retained at the University. Values above the bars in the top graph represent counts; all others represent percentages. For each of the study's six NFRS cohorts, this figure shows the numbers (grey bars) and percentages (line) who were not retained in the fall following their admit term/year. Abbreviations: FA09=fall 2009; FA10=fall 2010; FA11=fall 2011, FA12=fall 2012; FA13=fall 2013; FA14=fall 2014 
Figure 5 shows TRAN attrition data disaggregated by cohort. The number of TRAN who were not retained in the fall term following their admit term/year ranged from 33 (FA10 cohort) to 63 (FA11 and FA13 cohorts). The lowest percentage of these TRAN was 11.3 (FA10 cohort) and the highest was 16.6 (FA11 cohort). Thus, a maximum of about $17 \%$ of the TRAN in this study's cohorts was not retained. The two most frequent attrition reasons were decided not to attend the University (i.e., TRAN who submitted SIRs but never attended classes at the University) and leave of absence to serve in the military (South Korean males). Poor academic performance (resulting in disqualification or subject to disqualification) was the third most frequent reason. Other reasons were academic dishonesty, transferred to another institution, and stopped attending the University. For each of these reasons, within each cohort, the percentage was $5 \%$ or less (data displays available from the author upon request).

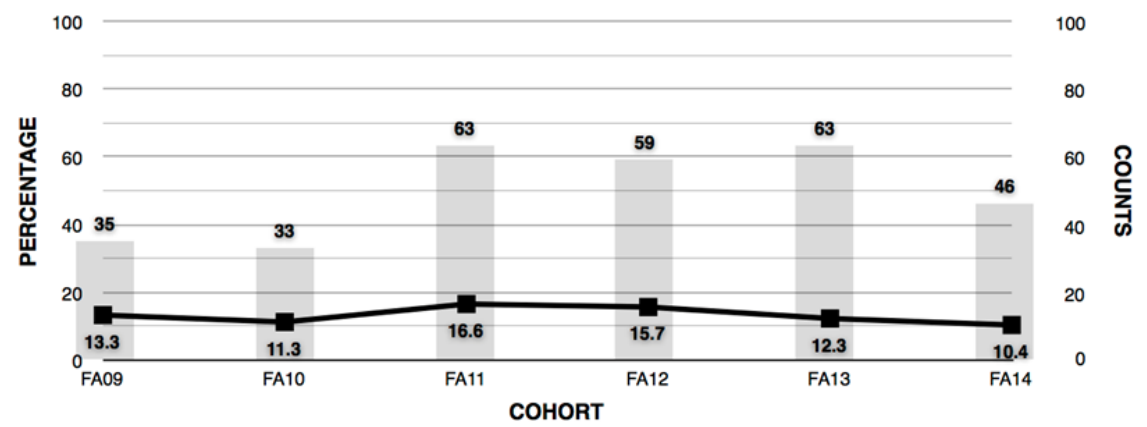

Figure 5. International transfer students' (TRAN) attrition rates and reasons for not being retained at the University. Values above the bars in the top graph represent counts; all others represent percentages. For each of the study's six TRAN cohorts, this figure shows the numbers (grey bars) and percentages (line) who were not retained in the fall following their admit term/year. Abbreviations: FA09=fall 2009; FA10=fall 2010; FA11=fall 2011, FA12=fall 2012; FA13=fall 2013; FA14=fall 2014

\section{Time to degree}

The average number of years for degrees to be conferred to the University's international undergraduates who graduated between AY 2010-11 and 2014-15, inclusive, disaggregated by applicant type (NFRS vs. TRAN), are shown in Figure 6. The time to degree averaged less than 4 years for NFRS and about 2 years for TRAN. Degrees were conferred in an average of 3.6 years to NFRS who graduated in AY 2013-14 or AY 201415; 3.7 years to NFRS who graduated in AY 2010-11; and 3.8 years to NFRS who graduated in AY 2011-12 or AY 2012-13. Degrees were conferred in an average of 1.9 years to TRAN who graduated in AY 201213, 2013-14, or 2014-15; 2.0 years to TRAN who graduated in AY 201112; and 2.1 years to TRAN who graduated in AY 2010-11. The annual number of NRFS to whom degrees were conferred between AY 2010-11 and 2014-15, inclusive, ranged from a low of 45 (AY 2011-12) to a high of 
212 (AY 2014-15). The corresponding TRAN values were 223 (AY 201011) and 300 (AY 2013-14).

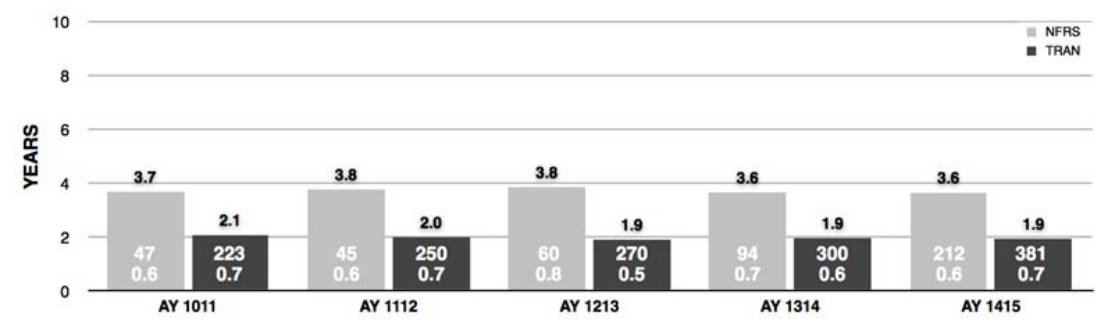

Figure 6. International undergraduates' time to degree at the University, disaggregated by applicant type. Values above the bars represent number of years. Values within the bars represent counts and standard deviations. Abbreviations: AY=academic year; NFRS=first-time freshmen; TRAN=transfer students

\section{DISCUSSION AND CONCLUSIONS}

The present study was conducted to achieve three goals. The first goal was to test the hypothesis that international undergraduates attending the University during the recent period of dramatic enrollment growth would have low retention and graduation rates. If this hypothesis were confirmed, it would support the concern of administrators, faculty, and staff that the University's international undergraduates collectively were struggling academically. A second goal was to measure the time to degree for the University's international undergraduates who graduated during the five most recent AYs. This measurement could provide further support for the concern about these students' academic struggles. The present study's third goal was to identify what reasons were responsible for attrition of the University's international undergraduates. If these students in fact were collectively struggling academically, then the ones who were not retained and/or did not graduate should have done so primarily (if not exclusively) as a consequence of low GPAs.

To achieve the above goals, the following four questions were addressed. First, for this study's six cohorts, how many and what percentage of the University's international NFRS and TRAN were retained in their second fall term? The cohorts' number of retained NFRS ranged from a low of 49 to a high of 855 and the percentage ranged from a low just under $85 \%$ to a high of $94 \%$. The corresponding values for TRAN ranged from 228 to 449 and from $84 \%$ to $90 \%$, respectively. These findings indicated that the University's international undergraduates were retained to a higher degree than what would be expected if 1) these students collectively were struggling academically, and 2) TRAN were inadequately prepared for the University's academic rigor.

Second, for this study's six cohorts, how many and what percentage of international NFRS and TRAN graduated from the University? The 
cohorts' number and percentage of NFRS with conferred degrees ranged from a low of 0 to a high of 173 and from a low of $0 \%$ (1- and 2-year graduation rates) to a high just under $83 \%$ (6-year rate), respectively. The corresponding values for TRAN ranged from 3 to 314 and from just under $1 \%$ (1-year rate) to just under 92\% (5-year rate), respectively. These findings similarly indicated that the University's international undergraduates graduated to a higher degree than what would be expected.

Third, what reasons were responsible for the University's NFRS and TRAN who did not graduate and/or were not retained? What percentage was due to low GPAs (academic struggling)? The two most frequent attrition reasons were leave of absence to serve in the military (South Korean males) and decided not to attend the University (i.e., NFRS and TRAN who submitted SIRs but never attended classes at the University). Poor academic performance was the third most frequent reason. The number of NFRS who were not retained in their second year at the University ranged from 3 to 89, and the percentages ranged from 5.8 to 15.2. Corresponding values for TRAN were 33 to 63 and $11.3 \%$ to $16.6 \%$. These findings, like the ones above, are inconsistent with what would be expected.

Lastly, for all international NFRS and TRAN who graduated from the University, regardless of the cohort to which they belonged, what was their time to degree? These students' time to degree averaged less than 4 years for NFRS and about 2 years for TRAN. By convention, first-time freshmen would be expected to take 4 years (freshman through senior years, inclusive) to complete their program of study and graduate; transfer students would be expected to take 2 years (junior and senior years). The University's NFRS and TRAN therefore, on average, slightly bettered or met the conventional time to degree. This finding, like the others in the present study, did not confirm expectations.

The present study supported the conclusion that answers to the above four research questions, taken together, disconfirmed the hypothesis that international undergraduates attending the University during the recent period of dramatic enrollment growth would have low retention and graduation rates. Additionally and importantly, this study's attrition analysis supported the conclusion that low GPA leading to dismissal was neither the exclusive nor primary reason why NFRS and TRAN did not graduate and/or were not retained. Instead, leave of absence for compulsory service in South Korea's military (Conscription in South Korea, n.d.) and decided not to attend classes at the University (i.e., NFRS and TRAN who submitted SIRs but never enrolled at the University) were the two most frequent attrition reasons these students. The present findings therefore are consistent with previous ones (Dorado \& Fass-Holmes, 2016; Fass-Holmes \& Vaughn, 2014, 2015) (see also Korobova, \& Starobin, 2015; Mamiseishvili, 2012; Meagher, 2014) and support the conclusion that the University's 
international undergraduates generally have succeeded academically rather than struggled.

Concerns among the University's administrators, faculty, and staff that international undergraduates collectively struggle academically have been accompanied by concerns about widespread cheating (Bertram Gallant et al., 2015; Fass-Holmes \& Dorado, unpublished observations; FassHolmes \& Vaughn, 2014, 2015). These concerns could be interrelated; anecdotal evidence suggests that administrators, faculty, and staff think their international students collectively struggle academically due to English weakness and therefore collectively resort to violating academic integrity policies (Fass-Holmes \& Dorado, unpublished observations). Although recent findings do not support the view that cheating is widespread among the University's international students (Fass-Holmes, in press), the present results possibly could be explained by cheating. Additional research will be necessary to test this possibility.

Two notable limitations must be taken into consideration with regard to the above conclusions. The first is that, since this study focuses on a single university, these findings' generalizability and interpretation are limited. Studies at other universities will be needed to determine generalizability. The second limitation is that insufficient time has elapsed to measure the graduation rate of the University's two most recent NFRS and TRAN cohorts (which also are its largest). Analyses comparable to the ones in the present study will need to be repeated for the FA13 and FA14 cohorts over several more years to measure 5- and 6-year graduation rates for NFRS, and 2- and 3-year rates for TRAN.

\section{IMPLICATIONS}

The present results have administrative, policy, and theoretical implications. An administrative implication pertains to programs and services intended to optimize student engagement and satisfaction which, in turn, promote retention and graduation. The concept of engagement refers to students' involvement or interest in learning and their connectedness to their classes, institutions, and each other (Axelson \& Flick, 2010). Numerous studies have shown that undergraduates' learning is enhanced when they are educationally engaged/involved (e.g., Kuh, 2003; Zhao, Kuh, \& Carini, 2005), and that engagement is essential for student retention (Astin, 1984; Tinto, 2007). The concept of satisfaction refers to the quality of experience with instruction, curriculum, faculty, other students, the administration, and facilities (Astin, 1993). Satisfaction also is essential for student success (Astin, 1993) and positively associated with retention (Elliott \& Healy, 2001; Korobova \& Starobin, 2015; Schertzer \& Schertzer, 2004). To the extent that international students' retention and graduation rates reflect their 
level of engagement and satisfaction, administrators could decide to maintain (rather than adjust) the level of relevant support programs and services (e.g., Yan \& Sendall, 2016). This would be prudent, to ensure that scarce state funding and/or other limited resources are allocated optimally.

Another administrative implication of the present findings pertains to the use of retention and graduation rates for accountability purposes (Gold \& Albert, 2006). Results of the attrition reasons analysis raise the question of whether the University, which has substantial numbers of South Korean male students (Dorado \& Fass-Holmes, 2016), should be held accountable for the negative impact of these students' early departure on the school's retention and graduation rates. This question also would be relevant for the NFRS and TRAN who submitted SIRs but then did not enroll at the University. Although the latter students by definition were not "retained" since they did not enroll during their admit year (U.S. Department of Education, n.d.), they chose not to enroll for at least some of the same reasons why enrolled counterparts would not be retained in the following year-finances, better fit at another institution, location, etc. (Choudaha \& Schulmann, 2014; Schulmann \& Choudaha, 2014). The University's retention and graduation rates would look more favorable than those in the present study if these two groups of students (South Korean males; ones who submitted SIRs but did not enroll) were excluded from the rates' computations.

If universities should not be held accountable for South Korean males, students who submit SIRs but never attend, and/or any other group of internationals whose circumstances are outside of the school's control, then what policy should be adopted accordingly? One possibility would be to implement a policy which denies admission to all South Korean male applicants eligible for compulsory military service. Such a policy would be discriminatory, however. Another possibility would be to continue admitting qualified South Korean male applicants, but exclude them from retention and graduation rates' computations. This possibility also would be discriminatory, however, and it additionally could be impractical for higher education institutions with substantial numbers of such students and/or could have implications for compliance with the federal Student Right to Know and Campus Security Act (Cook \& Pullaro, 2010). A third possibility would be to continue admitting such students and including them in retention and graduation rate computations, but also compute and report comparison values without them.

A theoretical implication of the present study pertains to student retention models (e.g., Astin, 1984; Bean, 1980, 1982; Tinto, 1975). These models address factors and variables (such as affordability, lack of access to jobs, and transfer to another university) which have been shown to influence students' decision to leave school prior to completion (Choudaha \& 
Schulmann, 2014). However, they do not account for international students' unique challenges-English writing (Benzie, 2010; Center for Research on Learning and Teaching, 2016; Leong, 2015; Lin \& Scherz, 2014; Ren et al., 2007), mandatory compliance with federal immigration regulations (Urias \& Leakey, 2009), and lack of familiarity with Western academic integrity standards and/or teaching methods (Hanassab \& Tidwell, 2002; Sherry et al., 2010; Simpson, 2016). To the extent that the University's NFRS and TRAN cohorts in this study were affected by these unique challenges, they nevertheless were successful as evidenced by their retention rate, graduation rate, and time to degree. Additional research will be needed to determine the extent to which international students' retention, graduation, and/or time to degree in fact are affected by these unique challenges. They potentially then could be accounted for in retention models and theories.

In summary, the present study's findings have administrative, policy, and theoretical implications. The administrative implications pertain to programs and services intended to optimize student engagement and satisfaction and consequently promote retention and graduation, the policy implications pertain to South Korean males and other groups of internationals whose circumstances leading to early departure are beyond a school's control, and the theoretical implications pertain to the potential effect of international students' unique challenges on retention and graduation. Despite this study's limitation to a single higher education institution, it could serve as a model for other American universities to replicate and use in making data-driven decisions about administration, policy, and organizational strategy which affect international students.

\section{REFERENCES}

Aljohani, O. (2016). A review of the contemporary international literature on student retention in higher education. International Journal of Education \& Literacy Studies, 4(1), 40-52.

Andrade, M. S. (2006a). International students in English-speaking universities: Adjustment factors. Journal of Research in International Education, 5(2), 131-154.

Andrade, M. S. (2006b). International student persistence: Integration or cultural integrity?. Journal of College Student Retention: Research, Theory \& Practice, 8(1), 57-81.

Arab Academy. (2010). What are the different forms of Arabic? Retrieved from http://www.arabacademy.com/arabic-blog/arabic-language/what-are-thedifferent-forms-of-arabic/

Asimov, N., \& Gutierrez, M. (2015). UC president, governor agree to freeze tuition for 2 years. Retrieved from http://www.sfgate.com/education/article/ Napolitano-Jerry-Brown-strike-deal-on-UC-tuition-6263588.php

Astin, A. W. (1984). Student involvement: A developmental theory for higher education. Journal of College Student Personnel, 25(4), 297-308. 
Astin, A. W. (1993). What matters in college? Four critical years revisited. San Francisco, CA: Jossey-Bass.

Axelson, R. D. \& Flick, A. (2010). Defining student engagement. Change: The Magazine of Higher Learning, 43(1), 38-43.

Bean, J. (1982). Conceptual models of student attrition: How theory can help the institutional researcher. New Directions for Institutional Research, 1982(36), 17-33.

Bean, J. P., \& Metzner, B. S. (1985). A conceptual model of nontraditional undergraduate student attrition. Review of Educational Research, 55(4), 485-540.

Benzie, H. J. (2010). Graduating as a 'native speaker': International students and English language proficiency in higher education. Higher Education Research \& Development, 29(4), 447-459.

Berger, J. B., Ramírez, G. B., \& Lyons, S. (2012). Past to present-A historical look at retention. In A. Seidman (Ed.), College Student Retention: Formula for Student Success (Second Edition) (pp.7-34). Lanham, MD: Rowman \& Littlefield Publishers.

Bertram Galant, T., Binkin, N., \& Donohue, M. (2015). Students at risk for being reported for cheating. Journal of Academic Ethics, 13(3), 217-228.

Bista, K. (2011). Academic dishonesty among international students in higher education. In J. Miller \& J. Groccia (Eds.), To Improve the Academy: Vol. 30. Resources for Faculty, Instructional, and Organizational Development (pp. 159-172). San Francisco, CA: Jossey-Bass.

Cabrera, A. F., Nora, A., \& Castaneda, M. B. (1993). College persistence: Structural equations modeling test of an integrated model of student retention. Journal of Higher Education, 64(2), 123-139.

Center for Research on Learning and Teaching. (2016). Teaching international students: Pedagogical issues and strategies. Retrieved from http://www.crlt.umich.edu/print/748

Choudaha, R., \& Schulmann, P. (2014). Bridging the gap: Recruitment and retention to improve international student experiences. Retrieved from http://www.nafsa.org/epubs

Conscription in South Korea. (n.d.). In Wikipedia. Retrieved from https://en.wikipedia.org/wiki/Conscription_in_South_Korea

Cook, B., \& Pullaro, N. (2010). College graduation rates: Behind the numbers. Retrieved from http://www.acenet.edu/news-room/Documents/CollegeGraduation-Rates-Behind-the-Numbers.pdf

Di Maria, D. L., \& Kwai, C. K. (2014). Developing an international student retention strategy. Theory to practice. Retrieved from http://www.aieaworld.org/assets/docs/Conference_Materials/2014/docstou pload2/di\%20maria\%20kwai\%20presentation.pdf

Dorado, D. A. L., \& Fass-Holmes, B. (2016). Academic achievement and demographics of international undergraduates. In K. Bista \& C. Foster (Eds.), Exploring the Social and Academic Experiences of International Students in Higher Education Institutions (pp. 227-252). Hershey, PA: IGI Global. 
Elliott, K. M., \& Healy, M. A. (2001). Key factors influencing student satisfaction related to recruitment and retention. Journal of Marketing for Higher Education, 10(4), 1-11. DOI: 10.1300/J050v10n04_01

Fass-Holmes, B. (in press). Demographics, retention, and graduation of international students reported for academic integrity violations. Journal of International Students.

Fass-Holmes, B., \& Vaughn, A. A. (2014). Are international undergraduates struggling academically? Journal of International Students, 4(1), 60-73.

Fass-Holmes, B., \& Vaughn, A. A. (2015). Evidence that international undergraduates can succeed academically despite struggling with English. Journal of International Students, 5(3), 228-243.

Feal, S. (2008). When international students get into immigration trouble...Retrieved

from http://www.nafsa.org/_/file/_/ac08sessions/rh010.pdf

Frankfurt International School. (n.d., a). The differences between English and Arabic. Retrieved from http://esl.fis.edu/grammar/langdiff/arabic.htm

Frankfurt International School. (n.d., b). The differences between English and Chinese. Retrieved from http://esl.fis.edu/grammar/langdiff/chinese.htm

Gautam, C., Lowery, C. L., Mays, C., \& Durant, D. (2016). Challenges for global learners: A qualitative study of the concerns and difficulties of international students. Journal of International Students, 6(2), 501-526.

Gold, L., \& Albert, L. (2006). Graduation rates as a measure of college accountability. American Academic, 2(1), 89-106.

Guo, P. (2009). Common English mistakes made by native Chinese speakers. Retrieved from http://www.pgbovine.net/chinese-english-mistakes.htm

Hanassab, S., \& Tidwell, R. (2002). International students in higher education: identification of needs and implications for policy and practice. Journal of Studies in International Education, 6(4), 305-322.

Institute of International Education. (2015a). Open Doors data international students: new international enrollment. Retrieved from http://www.iie.org/Research-and-Publications/Open-

Doors/Data/International-Students/New-International-Enrollment/2004-15

Institute of International Education. (2015b). Open Doors data international students: all places of origin. Retrieved from http://iie.org/Research-andPublications/Open-Doors/Data/International-Students/All-Places-ofOrigin/2013-15

Jackson, M., Ray, S., \& Bybell, D. (2013). International students in the U.S.: Social and psychological adjustment. Journal of International Students, 3(1), 1728.

Japanese-Language. (n.d.). Japanese dialects. Retrieved from http://www.japaneselanguage.org/japanese/dialects.asp

Korobova, N., \& Starobin, S. S. (2015). A comparative study of student engagement, satisfaction, and academic success among international and American students. Journal of International Students, 5(1), 72-85.

Kuh, G. D. (2003). What we're learning about student engagement from NSSE: Benchmarks for effective educational practices. Change: The Magazine of Higher Learning, 35(2), 24-32. 
Kuh, G. D., Kinzie, J., Buckley, J. A., Bridges, B. K., \& Hayek, J. C. (2006). What Matters to Student Success: A Review of the Literature. Washington, D.C.: National Postsecondary Education Cooperative.

Kuo, Y-H. (2011). Language challenges faced by international graduate students in the United States. Journal of International Students, 1(2), 38-42.

Kwai, C. K. (2009). Model of international student persistence: Factors influencing retention of international undergraduate students at two public statewide four-year university systems.(Doctoral dissertation). Retrieved from ProQuest Dissertations and Theses. (Accession Order No. UMI 3390997)

Languages of China. (n.d.). The Chinese language. Retrieved from http://www.chinalanguage.com

Leong, P. (2015). Coming to America: Assessing the patterns of acculturation, friendship formation, and the academic experiences of international students at a U.S. College. Journal of International Students, 5(4), 459474.

Lin, S-Y., \& Scherz, S. D. (2014). Challenges facing Asian international graduate students in the US: Pedagogical considerations in higher education. Journal of International Students, 4(1), 16-33.

Lupton, R. A., Chapman, K. J., \& Weiss, J. E. (2010). A cross-national exploration of business students' attitudes, perceptions, and tendencies toward academic dishonesty. Journal of Education for Business, 75(4), 231-235.

Mamiseishvili, K. (2012). International student persistence in U.S. postsecondary institutions. Higher Education, 64(1), 1-17.

Mantle, D. R. (2003). What foreign students fear: Homeland Security measures and closed deportation hearings. Brigham Young University Education and Law Journal, 2003(2), 815-834.

Meagher, B. (2014). International student degree completion rates. Retrieved from http://blog.shorelight.com/international-student-degree-completion-rates

Mori, S. (2000). Addressing the mental health concerns of international students. Journal of Counseling \& Development, 78(2), 137-144.

NAFSA: Association of International Educators. (2016). NAFSA Advisor's Manual 360. Retrieved from https://www.nafsa.org/_file/_/amresource /8cfr2142f.htm

Obama, B. (2009). State of the Union Address. Retrieved from http://stateoftheunionaddress.org/2009-barack-obama

Oliver, R., Vanderford, S., \& Grote, E. (2012). Evidence of English language proficiency and academic achievement of non-English-speaking background students. Higher Education Research \& Development, 31(4), 541-555.

Ota, A. (2013). Factors influencing social, cultural, and academic transitions of Chinese international ESL students in U.S. higher education. (Doctoral dissertation). Portland State University.

Pascarella, E. T. (1980). Student-faculty informal contact and college outcomes. Review of Educational Research, 50(4), 545-595.

Perry, C. J. (2016). Comparing international and American students' challenges: A literature review. Journal of International Students, 6(3), 712-721. 
Ren, J., Bryan, K., Min, Y., \& Wei, Y. (2007). Language preparation and the first year experience: What administrators and policy makers should know. Florida Journal of Educational Administration \& Policy, 1(1), 11-24.

Roy, S. R. (2013). Educating Chinese, Japanese, and Korean international students: Recommendations to American professors. Journal of International Students, 3(1), 10-16.

Schertzer, C. B., \& Schertzer, S. M. B. (2004). Student satisfaction and retention: A conceptual model. Journal of Marketing for Higher Education, 14(1), 79_ 91. DOI: 10.1300/J050v14n01_05

Schulmann, P., \& Choudaha, R. (2014). International student retention and success: A comparative perspective. Retrieved from http://wenr.wes.org/2014/09/ international-student-retention-and-success-a-comparative-perspective/

Sherry, M., Thomas, P., \& Chui, W. H. (2010). International students: a vulnerable student population. Higher Education, 60(1), 33-46.

Simpson, D. (2016). Academic dishonesty: An international student perspective. Academic Perspectives in Higher Education, 2(5), 1-21.

Smithee, M., Greenblatt, S. L., \& Eland, A. (2004). U.S. culture series: U.S. classroom culture. Retrieved from http://www.nafsa.org/uploadedFiles/

NAFSA_Home/Resource_Library_Assets/Publications_Library/u.s.pdf

Tinto, V. (1975). Dropout from higher education: A theoretical synthesis of recent research. Review of Educational Research, 45(1), 89-125.

Tinto, V. (2007). Research and practice of student retention: What next? Journal of College Student Retention Research, 8(1), 1-19.

U.S. Department of Education. (n.d.). What are graduation, retention, and transfer rates? Retrieved from https://fafsa.ed.gov/help/fotw91n.htm

U.S. Immigration and Customs Enforcement. (2015). F and M student record termination reasons in SEVIS. Retrieved from https://www.ice.gov/factsheets/f-and-m-student-record-terminationreasons-sevis

U.S. News \& World Report. (2015). Top public schools national universities. Retrieved from http://colleges.usnews.rankingsandreviews.com/bestcolleges/rankings/national-universities/top-public

Urias, D. A., \& Yeakey, C. C. (2005). International students and U.S. border security. The NEA Higher Education Journal, 187-198.

Urias, D. A., \& Yeakey, C. C. (2009). Analysis of the U.S. student visa system. Misperceptions, barriers, and consequences. Journal of Studies in International Education, 13(1), 72-109.

Vaughn, A. A., Bergman, M., \& Fass-Holmes, B. (2015). Nonresident undergraduates' performance in English writing classes-hierarchical linear modeling analysis. Journal of International Students, 5(4), 319-333.

Yan, K., \& Berliner, D. C. (2013). Chinese international students' personal and sociocultural stressors in the United States. Journal of College Student Development, 54(1), 62-84. doi:10.1353/csd.2013.0010

Yan, Z., \& Sendall, P. (2016). First year experience: How we can better assist firstyear international students in higher education. Journal of International Students, 6(1), 35-51. 
Yildirim, Ö. (2014). Adjustment problems of international students studying in the U.S.A.: The effects of English language and academic culture. International Journal of Global Education, 3(4), 1-23.

Yin-Croft, X-L. (2012). From the classroom: Working with Chinese ELLs. Retrieved from http://www.colorincolorado.org/article/classroom-workingchinese-ells

Zhao, C-M., Kuh, G. D., \& Carini, R. M. (2005). A comparison of international student and American student engagement in effective educational practice. Journal of Higher Education, 76(2), 209-231.

BARRY FASS-HOLMES, PhD, is the Analytical Studies Coordinator for the International Students \& Programs Office in the International Center at the University of California, San Diego. He studies international students' academic achievement. Email: bfholmes@ucsd.edu

Manuscript submitted: June 15, 2016 Manuscript Revised: September 26, 2016 Accepted for publication: October 24, 2016 